\title{
URGENSI PEMBATASAN PENANGANAN REPRESIF APARAT KEPOLISIAN DALAM MENANGGULANGI RADIKALISME
}

\author{
Alwin Widyanto Hartanto ${ }^{1}$, Ellyzabeth Tanaya ${ }^{2}$ dan Hansel $\mathrm{Ng}^{3}$ \\ Fakultas Hukum Universitas Tarumanagara Jakarta \\ ${ }^{1}$ Email: alwinwh@hotmail.com \\ Fakultas Hukum Universitas Tarumanagara Jakarta \\ ${ }^{2}$ Email: ellyzabeth_tan@yahoo.com \\ Fakultas Hukum Universitas Tarumanagara Jakarta \\ ${ }^{3}$ Email: hansel.ihang@gmail.com
}

\begin{abstract}
ABSTRAK
Radikalisme merupakan isu yang menjadi masalah di berbagai belahan dunia, termasuk Indonesia. Agar permasalahan radikalisme tidak terus berkembang, diperlukan upaya untuk menanggulangi perkembangan radikalisme. Salah satu lembaga yang bertugas untuk menanggulangi radikalisme adalah kepolisian. Ketika menjalankan tugasnya, polisi dapat mengambil tindakan-tindakan, baik tindakan yang bersifat pencegahan maupun tindakan yang bersifat represif. Akan tetapi, diperlukan adanya pembatasan-pembatasan yang perlu diperhatikan saat menanggulangi radikalisme menggunakan cara-cara represif. Tulisan ini bertujuan untuk menganalisis pentingnya pembatasan tindakan represif oleh aparat kepolisian serta upaya-upaya yang dapat dilakukan untuk meningkatkan kinerja kepolisian dalam menanggulangi radikalisme. Melalui penelitian ini, dapat disimpulkan bahwa dalam penanggulangan radikalisme, aparat kepolisian perlu membatasi penggunaan tindakan represif dan menggunakannya hanya jika diperlukan, misalnya ketika eskalasi masalah terlanjur besar dan tindakan pencegahan tidak lagi dimungkinkan. Hal ini disebabkan oleh tindakan represif yang cenderung tidak efektif untuk menyelesaikan permasalahan radikalisme. Selain itu, upaya-upaya peningkatan kinerja kepolisian dapat dilakukan agar radikalisme dapat ditangani secara lebih efektif.
\end{abstract}

Kata kunci: radikalisme, kepolisian, penanggulangan, represif

\section{PENDAHULUAN \\ Latar Belakang}

Hak asasi manusia merupakan hak yang diakui secara global. Pandangan ini dapat dapat dibuktikan dengan adanya berbagai perangkat yang menjamin agar hak tersebut dapat dinikmati oleh manusia secara penuh. Perlindungan terhadap hak asasi manusia pertama kali diungkapkan dalam Universal Declaration of Human Rights (UDHR) yang ditandatangani oleh anggota Perserikatan Bangsa-Bangsa (PBB) pada tahun 1948. UDHR ini sekarang menjadi sumber dari seluruh perangkat mengenai hak asasi manusia. Di Indonesia sendiri, hak asasi manusia diatur dalam pasal 28 A-J Undang-Undang Dasar Negara Republik Indonesia tahun 1945 (UUD NRI 1945). Salah satu hak yang dijamin oleh UUD NRI 1945 ialah hak atas rasa aman. Pada pasal 28 G UUD NRI 1945, disebutkan bahwa setiap orang berhak atas rasa aman dan perlindungan dari ancaman ketakutan untuk berbuat atau tidak berbuat sesuatu yang merupakan hak asasi.

Meskipun hak atas rasa aman dijamin oleh Undang-Undang Dasar, namun pada kenyataannya banyak peristiwa di dunia yang justru jauh dari kata aman. Hal ini disebabkan oleh adanya kelompok-kelompok tertentu yang menggunakan cara-cara ekstrem untuk menciptakan perubahan secara total dan revolusioner dengan menjungkirbalikkan nilai-nilai yang ada secara drastis lewat kekerasan (violence) dan aksi-aksi ekstrem (BNPT, 2016). Paham yang menggunakan cara-cara ekstrem tersebut kini lebih dikenal sebagai radikalisme. Perkembangan radikalisme dapat ditelusuri sejak awal abad ke-18 di Inggris ketika muncul gerakan penolakan dari rakyat jelata terhadap perlindungan yang diberikan pemerintah kepada para tuan-tuan tanah. 
Seiring perkembangannya, gerakan-gerakan radikal mulai menyentuh ranah politik dan mulai berubah tujuan utamanya, yaitu menginginkan perubahan atau pembaharuan sosial dan politik dengan cara yang ekstrem dan drastis, yaitu kekerasan.

Radikalisme kini menjadi isu yang selalu menjadi sorotan dan dialami berbagai penjuru dunia. Di Afganistan misalnya, dikenal suatu jaringan terorisme al-Qaeda yang pada awalnya merupakan gerakan radikal yang timbul karena ketidakadilan global dan ketidakpuasan atas fenomena politik. Contoh-contoh gerakan radikal lain ialah gerakan separatis di Amerika Serikat, gerakan pembantaian etnis Rohingya di Myanmar, hingga berkembangnya konsep Negara Islam Irak dan Suriah ("ISIS"). Ini menunjukkan bahwa radikalisme sendiri merupakan hal yang bersifat universal dan merupakan suatu konsep yang dikenal di seluruh dunia.

Sejak kemerdekaannya, Indonesia sudah mengalami berbagai serangan dari kelompok-kelompok radikal. Beberapa contoh di antaranya ialah gerakan DI/TII (Darul Islam/Tentara Islam Indonesia) pada tahun 1949 yang ingin menjadikan hukum syariat sebagai dasar negara, rangkaian kerusuhan di Maluku, aksi-aksi terorisme pada awal tahun 2000-an yang diwarnai dengan maraknya aksi-aksi bom bunuh diri, munculnya gerakan-gerakan separatis hingga berkembangnya jaringan ISIS di Indonesia yang terjadi belakangan ini. Semua gerakan radikal itu pada umumnya memiliki satu kesamaan meskipun motifnya berbeda, yakni menggunakan cara-cara ekstrem yang menjurus pada kekerasan dan menimbulkan kekhawatiran pada orang banyak.

\section{Rumusan Masalah}

Sebagai negara hukum, Indonesia mempunyai kewajiban untuk melindungi segenap bangsa Indonesia dan memberikan jaminan rasa aman kepada warga negaranya sesuai dengan amanat UUD 1945. Kewajiban tersebut diwujudkan melalui struktur hukum, yaitu aparatur negara, substansi hukum, yaitu hukum positif dan budaya hukum, yaitu perilaku masyarakat (Murya, 2016). Aparatur negara yang bertugas untuk melindungi kepentingan, keamanan serta memberikan rasa aman kepada masyarakat adalah kepolisian. Kepolisian dalam menjalankan tugasnya sering dihadapkan pada kelompok-kelompok radikal. Untuk menangani kelompokkelompok tersebut, perlu dilakukan tindakan yang tepat agar penanggulangan radikalisme dapat efektif dan berjalan dengan baik. Selain itu, aparat kepolisian juga memerlukan batasan-batasan tertentu agar tindakan yang dilakukan tidak justru menimbulkan masalah-masalah baru. Untuk memahami lebih jauh mengenai pembatasan penanganan dan upaya-upaya yang dapat dilakukan oleh aparat kepolisian dalam penanggulangan radikalisme, maka akan diteliti dua rumusan masalah sebagai berikut:

1. Bagaimana urgensi pembatasan tindakan represif aparat kepolisian dalam menanggulangi radikalisme?

2. Upaya-upaya apakah yang dapat dilakukan untuk meningkatkan kinerja kepolisian dalam menanggulangi radikalisme?

\section{METODE PENELITIAN}

Metode yang digunakan untuk penelitian ini adalah penelitian hukum normatif. Pendekatan yang digunakan ialah pendekatan undang-undang (statute approach) dan pendekatan konsep (conceptual approach). Untuk penelitian ini, digunakan data sekunder berupa bahan hukum primer yang meliputi peraturan dan regulasi terutama yang terkait dengan kepolisian, bahan hukum sekunder yang meliputi buku teks dan tulisan-tulisan ilmiah untuk mendapatkan 
pandangan dan konsep terkait penegakan hukum terhadap radikalisme serta bahan-bahan non hukum berupa buku-buku non-hukum untuk menjawab isu terkait timbulnya radikalisme.

\section{HASIL DAN PEMBAHASAN}

\section{Pembatasan Tindakan Represif Aparat Kepolisian dalam Menanggulangi Radikalisme}

Radikalisme merupakan paham atau aliran yang menginginkan perubahan atau pembaharuan sosial dan politik dengan cara yang ekstrem dan drastis (Depdikbud, 1995). Para penganut paham radikal biasanya mempunyai sikap yang intoleran, fanatik, eksklusif, dan revolusioner. (BNPT, 2016). Idealisme yang dimiliki tiap kelompok radikal berbeda antara satu dengan yang lain. Meski begitu, ada satu unsur yang selalu lahir di setiap paham radikalisme, yaitu kekerasan. Bagi para penganut paham radikal, kekerasan merupakan cara yang tepat untuk memperjuangkan cita-cita dan menyukseskan tujuan mereka. Kekerasan sendiri merupakan perbuatan yang tidak sesuai dengan norma-norma yang berlaku dalam masyarakat. Oleh sebab itu, perlu ada tindakan yang tepat untuk menanggulangi paham radikalisme agar tidak kemudian berkembang dan membahayakan masyarakat.

Salah satu aparat negara yang memiliki tugas untuk menanggulangi permasalahan radikalisme itu adalah kepolisian. Hal ini sesuai dengan amanat Pasal 4 Undang-Undang Nomor 2 Tahun 2002 tentang Kepolisian Negara Republik Indonesia ("UU Kepolisian") yang menyatakan bahwa kepolisian bertujuan untuk mewujudkan keamanan dalam negeri yang meliputi terpeliharanya keamanan dan ketertiban masyarakat, tertib dan tegaknya hukum, terselenggaranya perlindungan, pengayoman, dan pelayanan kepada masyarakat, serta terbinanya ketenteraman masyarakat dengan menjunjung tinggi hak asasi manusia. Menanggulangi terjadinya kekerasan dan paham radikal tentunya merupakan salah satu tugas polisi yang penting dalam melindungi dan menjaga ketenteraman masyarakat.

Strategi penanggulangan radikalisme yang diimplementasikan kepolisian dapat dilakukan baik melalui upaya-upaya pencegahan (preventif) maupun upaya-upaya represif. Pada umumnya, upaya-upaya pencegahan perlu didahulukan dalam menanggulangi radikalisme. Hal ini juga dinyatakan secara jelas dalam penjelasan umum UU Kepolisian yang menyatakan bahwa tindakan pencegahan tetap diutamakan melalui pengembangan asas preventif, dan ketentuan Pasal 19 Ayat (2) yang menyebutkan Kepolisian Negara Republik Indonesia mengutamakan tindakan pencegahan. Untuk mencegah terjadinya suatu kekerasan yang disebabkan oleh paham radikal, maka strategi pencegahan yang dilakukan juga harus didasarkan pada penghapusan sebab-sebab dan kondisi yang menimbulkannya (Arief, 2008). Artinya, kepolisian harus terlebih dahulu mengetahui penyebab berkembangnya radikalisme. Faktor yang mempengaruhi perkembangan radikalisme di Indonesia bisa terdiri dari berbagai aspek, seperti pendidikan, ekonomi, budaya, agama, perkembangan teknologi dan informasi, dan lemahnya pendidikan karakter dalam masyarakat.

Selain mengetahui penyebab berkembangnya radikalisme, ada beberapa upaya yang bisa dilakukan aparat kepolisian untuk mencegah perkembangan radikalisme. Pertama, kepolisian perlu mengedepankan pembangunan karakter dan harus ikut berperan aktif dalam menanamkan nilai-nilai Pancasila sesuai dengan amanat Presiden. Kedua, kepolisian dapat menggandeng pemuka agama untuk memberi pencerahan pemikiran atau pengubahan pola pikir keagamaan tentang pandangan-pandangan radikal. Ketiga, kepolisian dapat mencoba untuk berdialog langsung dengan masyarakat melalui penyuluhan, seminar, dan iklan. Terakhir, pencegahan dapat dilakukan melalui kontrol dalam masyarakat. Melalui kontrol dan pengawasan yang ketat, 
pihak kepolisian dapat menghilangkan kesempatan-kesempatan yang memungkinkan kelompok radikal melakukan aksinya.

Bila upaya pencegahan sudah tidak bisa lagi digunakan, upaya represif terhadap paham radikal perlu dilakukan. Mengutip pendapat Hery Firmansyah (2011), upaya penanggulangan kejahatan pada hakikatnya merupakan suatu usaha untuk pengamanan masyarakat (social defence) agar masyarakat dapat terhindar dari kejahatan. Salah satu upaya penanggulangan itu dapat dilakukan melalui upaya-upaya represif, misalnya dengan melakukan penindakan terhadap kelompokkelompok radikal yang telah menggunakan cara-cara melawan hukum seperti kekerasan, hingga melakukan penyerbuan terhadap kelompok-kelompok radikal yang sedang menjalankan aksinya. Memang, tindakan represif untuk mengatasi masalah radikalisme perlu dihindari. Akan tetapi, hal ini bukan berarti bahwa tindakan represif tidak boleh digunakan sama sekali. Ketika eskalasi tindakan radikal itu sudah tinggi dan tidak dapat lagi dibendung, kepolisian tentunya harus menggunakan tindakan-tindakan represif untuk menekan dan menghentikan tindakan radikal yang dilakukan apalagi bila situasi mengharuskan digunakannya kekerasan untuk melawan kelompok radikal, misalnya ketika kelompok radikal telah melakukan perbuatan yang mengancam keselamatan baik kepolisian maupun warga sipil. Ketika hal yang demikian terjadi, tindakan represif dibutuhkan untuk mencegah terjadinya kejahatan berat atau yang mengancam jiwa orang.

Meskipun cara represif dapat digunakan oleh aparat kepolisian, pembatasan tetap saja diperlukan. Misalnya saat polisi melakukan penyerbuan, penggunaan senjata api dan penembakan terhadap kelompok radikal tetap perlu dihindari kecuali terpaksa. Hal ini juga diamanatkan dalam Pasal 47 Ayat (1) Peraturan Kepala Kepolisian Republik Indonesia ("Perkapolri") Nomor 8 Tahun 2009 tentang Implementasi Prinsip dan Standar Hak Asasi Manusia dalam Penyelenggaraan Tugas Kepolisian Negara Republik Indonesia yang menegaskan bahwa penggunaan senjata api hanya boleh digunakan bila benar-benar diperuntukkan untuk melindungi nyawa manusia. Pada prinsipnya, penggunaan senjata api merupakan upaya terakhir untuk menghentikan tindakan yang membahayakan keamanan jiwa. Apabila kepolisian masih memiliki cara lain untuk menangani situasi, penggunaan senjata api perlu dihindari, atau setidaknya dibatasi dengan tidak menembak bagian vital yang dapat mengancam nyawa pelaku tindak kejahatan.

Pembatasan penggunaan cara-cara represif sebetulnya memiliki makna tersendiri. Selain untuk menghindari adanya penyalahgunaan wewenang (abuse of power) oleh aparat kepolisian, penggunaan kekerasan untuk mengatasi kekerasan yang dilakukan kelompok radikal juga tidak efektif untuk menjawab permasalahan dan belum tentu dapat mencegah kejadian serupa untuk berulang. Lebih lagi, penggunaan cara-cara represif sebagai sarana utama penyelesaian masalah oleh kepolisian seakan menyamakan derajat aparat kepolisian dengan kelompok-kelompok radikal apabila aparat kepolisian ikut menggunakan cara-cara yang ekstrem dan penuh kekerasan untuk menyelesaikan masalah radikalisme. Selain itu, cara-cara kekerasan juga berpotensi menimbulkan masalah baru dan menimbulkan fanatisme buta dari kelompok radikal yang akan membalas kembali dengan kekerasan. Ini karena semakin represif gerakan melawan radikalisme dilakukan, semakin keras pula perlawanannya (Purwanto, 2007). Tentunya hal tersebut akan menjadi kontraproduktif dengan tujuan kepolisian untuk menanggulangi masalah radikalisme. Oleh sebab itu, cara-cara represif untuk menyelesaikan masalah radikalisme perlu dibatasi. Para kelompok radikal juga perlu diperlakukan secara manusiawi agar tidak ada tindakan balasan dari teman-temannya. 
Perlu disadari, perkembangan radikalisme hanya dapat ditanggulangi hingga ke akar-akarnya melalui penanganan dan tindakan yang tepat dan bijaksana. Bila kepolisian hanya menggunakan cara-cara represif untuk melawan radikalisme, akan tumbuh propaganda-propaganda dan pandangan radikal tertentu yang memusuhi kepolisian. Bila hal itu terjadi, kepolisian akan kesulitan untuk mengusut masalah radikalisme secara tuntas dan akan kehilangan kesempatan untuk menjalin hubungan untuk berdialog bersama kelompok-kelompok radikal agar penyelesaian masalah dapat dicari bersama dan membasmi radikalisme hingga ke akar permasalahannya.

\section{Upaya untuk Meningkatkan Kinerja Kepolisian dalam Menanggulangi Radikalisme}

Tugas utama dari aparat kepolisian adalah to protect and serve; untuk melindungi dan melayani masyarakat (Tjahjono, 2011). Oleh karena itu, aparat kepolisian sebagai salah satu jenis profesi hukum dalam melakukan segala tindakannya harus didasarkan pada moralitas, yaitn dengan (a) Berani berbuat dengan bertekad bertindak sesuai dengan tuntutan profesi, (b) sadar akan kewajibannya, dan (c) memiliki idealisme tinggi (Shidarta, 2009).

Aparat kepolisian dalam menjalankan profesinya harus berani bertindak demi kepentingan masyarakat. Saat menanggulangi radikalisme, misalnya, seorang polisi harus berani menggunakan cara-cara represif jika konflik yang disebabkan oleh kelompok radikal ini semakin mengalami eskalasi. Namun, seorang polisi haruslah sadar akan kewajiban utamanya, yaitu melindungi dan melayani masyarakat. Jika penanganan secara represif dirasa akan membahayakan keselamatan masyarakat, tentunya aparat kepolisian harus mendahulukan upayaupaya pencegahan. Jika memang masih bisa dilakukan, dua acara ini haruslah didahulukan. Aparat kepolisian harus mampu memosisikan diri kapan bertindak pre-emptif, kapan harus preventif dan kapan harus represif. Perlu adanya pembatasan diri pada aparat kepolisian dalam menjalankan tugasnya, jangan sampai terjadi apa yang disebut sebagai abuse of power.

Idealisme aparat kepolisian juga diperlukan agar bisa dipercaya oleh masyarakat. Banyak kasuskasus yang mencoreng nama POLRI sebagai aparat penegak hukum di Indonesia, bahkan sampai ada olok-olok legendaris yang menyatakan "Di Indonesia ini hanya ada tiga polisi yang tidak bisa disuap: Pertama, Hoegeng, kedua, patung polisi dan ketiga, polisi tidur!” (Supeno, 2010). Aparat kepolisian harus berani menolak jika ada tawaran-tawaran dari pihak yang berkepentingan. Tak bisa dipungkiri bahwa kelompok-kelompok radikal yang kuat mempunyai 'orang penting' di belakangnya yang siap untuk mendanai kegiatan mereka. Seorang polisi yang mempunyai idealisme tinggi tidak akan tergoda dengan tawaran-tawaran yang diberikan oleh orang penting tersebut. Aparat kepolisian juga perlu untuk mengedepankan pembangunan karakter. Peraturan Presiden Nomor 87 Tahun 2017 tentang Penguatan Pendidikan Karakter mengharapkan terciptanya bangsa Indonesia yang spiritual tetapi tetap nasionalis, dan mandiri tetapi tetap mengedepankan gotong royong. Pendidikan karakter merupakan kegiatan yang bersifat nasional dan merupakan tanggung jawab seluruh komponen bangsa dan negara. Kepolisian dalam hal ini tidak boleh menghiraukan pembangunan karakter dan harus ikut berperan aktif dalam menanamkan nilai-nilai Pancasila sesuai dengan amanat Presiden dalam korps kepolisian. Pancasila sebagai landasan ideologi negara juga memiliki nilai-nilai moral yang sangat baik untuk menguatkan idealisme aparat kepolisian dalam memerangi paham radikalisme.

Moralitas dalam melakukan profesi hukum membutuhkan proses, paling tidak harus dibina sejak calon penyandang profesi hukum tersebut dididik di bangku kuliah, bukan ketika yang bersangkutan sudah menjalankan tugasnya sebagai fungsionaris hukum. (Shidarta, 2009). Polisi sebagai salah satu profesi hukum juga memperoleh keahlian dan keterampilan ketika mereka 
mengikuti program pendidikan dan pelatihan lanjutan (Akademi Kepolisian). Namun. Selain harus mempunyai keahlian dan keterampilan di lapangan, aparat kepolisian juga harus mempunyai pengetahuan mendalam mengenai kasus-kasus yang mereka sedang ambil agar penanganannya menjadi maksimal. Aparat kepolisian dalam menangani kasus radikalisme haruslah mengetahui asal usul kelompok radikal tersebut, tujuan dari kelompok radikal tersebut, penyebab mengapa kelompok itu menjadi radikal, dan pengenalan lainnya. Bahkan, jika perlu, aparat kepolisian bisa menganggap dirinya bagian dari kelompok radikal, agar aparat kepolisian mengetahui bagaimana jalan pikiran dari kelompok radikal tersebut. Aparat kepolisian juga bisa menggunakan salah satu anggota radikal yang sudah ditangani untuk menjadi informan atau cepu sehingga penanganan terhadap kelompok radikal menjadi lebih mudah. Saat menjalankan tugasnya, aparat kepolisian juga harus mengetahui informasi dan teknologi terkini agar dapat mengikuti perkembangan suatu kasus, karena semakin negara berkembang ke arah modern, semakin banyak jenis kejahatan yang dapat terjadi.

Salah satu strategi yang perlu diambil oleh kepolisian untuk memberantas radikalisme ialah melalui pengembangan sumber daya manusia di dalam lembaga kepolisian. Perkembangan sumber daya polisi sangat penting untuk dapat mengimbangi perkembangan zaman dan kemajuan teknologi yang dimanfaatkan oleh kelompok-kelompok radikal. Kepolisian juga mampu berpikir untuk memahami cara kerja dari kelompok radikal agar dapat mencegah dan menanggulangi dampak gerakan-gerakan radikal yang mungkin dapat terjadi. Semua ini dapat dilakukan melalui peningkatan kualitas pendidikan internal kepolisian untuk meningkatkan kemampuan para anggota kepolisian. Kepolisian juga harus meningkatkan fungsi intelijen agar dapat mengetahui dengan baik situasi aktual di lapangan terkait gerakan dan perkembangan kelompok-kelompok radikal. Dengan begitu, kepolisian dapat menempatkan posisinya dan mengambil keputusan dengan lebih baik.

Keterampilan lapangan dan pengetahuan yang dimiliki aparat kepolisian juga harus diimbangi dengan hati nurani. Bekerja sebagai polisi, memberantas kejahatan, menanggulangi radikalisme, permasalahan-permasalahan bera ini begitu memberikan tekanan dan kepenatan. Oleh sebab itu penting bagi seorang polisi untuk menjaga hati nuraninya agar perbuatan aparat kepolisian tetap pada yurisdiksinya. Hati nurani berasal langsung dari Tuhan dan oleh karena itu tidak mungkin keliru. Apabila manusia menghadapi situasi konkret yang mengharuskannya memilih sikapsikap moral tertentu, maka yang hadir pada saat itu adalah suara hati (conscientia) (Sidharta, 2009). Suara hati bisa saja keliru apabila fakta dan data yang dijadikan bahan pertimbangan tidak valid, kurang lengkap, bahkan menyesatkan. Oleh karena itu, penggunaan hati nurani oleh aparat penegak hukum seperti polisi haruslah tepat dan sesuai proporsinya. Seorang polisi harus paham kapan akal perlu dikedepankan dan kapan hati nurani perlu digunakan. Filsafat hukum menjelaskan bahwa salah satu pertentangan dalam teori hukum ialah antara akal dan intuisi. Manusia yang selalu menggunakan akal akan selalu mengambil keputusan yang kasar, kejam dan brutal dalam menghadapi situasi tertentu. Di lain sisi, manusia yang menggunakan intuisi akan menghadapi sesuatu dengan hati nurani, yang mengakibatkan ketidakpastian dalam setiap pengambilan keputusan. Oleh karena itu, Immanuel Kant mengatakan, bahwa jalan tengah yang dapat diambil ialah bahwa "hati nurani dibutuhkan sebagai rem atau penahan dari tindakan akal yang kasar dan brutal”. Terkait dengan kinerja polisi dalam menanggulangi radikalisme, seorang polisi harus bisa menggunakan akal dan intuisi secara seimbang. Penggunaan akal yang dominan akan mengakibatkan tindakan yang brutal yang cenderung tidak efektif dalam menanggulangi radikalisme secara total, tetapi tindakan halus yang hanya mengandalkan hati nurani tidak dapat menyelesaikan permasalahan radikalisme secara utuh. Kembali lagi pada usaha menanggulangi 
radikalisme, seorang polisi harus bisa memosisikan diri, kapan saatnya menggunakan upayaupaya pencegahan, dan kapan tindakan-tindakan represif harus dilakukan.

Tak hanya berkutat pada bidang hukum, aparat kepolisian harus bersikap fleksibel untuk menerapkan bidang lain dan menjalankan profesinya, misalnya dengan menggunakan bidang sosial dan budaya. Seorang polisi harus bisa dengan mudah berbaur dan bersosialisasi dengan masyarakat agar kesadaran masyarakat akan hukum lebih mudah terbangun. Hal itu diterapkan melalui sosialisasi terhadap masyarakat dengan memberikan pemahaman untuk memerangi radikalisme. Selain itu, seorang polisi harus bisa menggunakan seni dan budaya untuk meningkatkan kesadaran masyarakat mengenai radikalisme. Budaya Indonesia merupakan budaya yang penuh dengan ramah tamah dan sopan santun dan jarang diwarnai dengan kekerasan. Budaya yang demikian perlu untuk dipertahankan dan digunakan dalam memerangi radikalisme yang sering kali menggunakan kekerasan. Hal ini sesuai dengan ucapan Bupati Purwakarta Dedi Mulyadi, bahwa "kebudayaan yang lahir di alam Indonesia diyakini dapat menjadi benteng perlawanan terhadap penyebaran paham-paham radikalisme." Dengan menerapkan kearifan lokal berupa budaya masyarakat, diharapkan kepolisian bisa menanggulangi radikalisme dengan baik.

\section{KESIMPULAN DAN SARAN}

\section{Kesimpulan}

1. Aparat kepolisian dalam menanggulangi radikalisme dapat menggunakan cara-cara pencegahan maupun cara-cara represif. Akan tetapi, tindakan-tindakan represif harus dibatasi dan digunakan hanya ketika cara-cara represif diperlukan, misalnya dalam hal eskalasi masalah yang terlanjur besar dan tindakan pencegahan tidak lagi dimungkinkan. Selain karena tindakan represif kurang efektif untuk menanggulangi radikalisme secara total, pembatasan penggunaan tindakan represif juga diperlukan untuk mencegah penyalahgunaan kewenangan oleh kepolisian.

2. Agar penanggulangan radikalisme lebih efektif, perlu dilakukan upaya-upaya peningkatan kinerja kepolisian, seperti mengedepankan pembangunan karakter, menanamkan unsur moralitas dalam diri, mengembangkan kualitas sebagai sumber daya manusia, memaksimalkan keterampilan lapangan dan pengetahuan yang diimbangi dengan hati nurani, serta tak menutup diri untuk menggunakan bidang-bidang lain di luar hukum untuk menanggulangi radikalisme.

\section{Saran}

Cara-cara kekerasan dalam penanggulangan radikalisme tidak efektif untuk menyelesaikan masalah dan berpotensi menimbulkan masalah baru. Oleh sebab itu, diperlukan penanganan yang tepat untuk menyelesaikan permasalahan radikalisme hingga ke akar-akarnya. Aparat kepolisian harus bisa membaca situasi dan melihat eskalasi radikalisme tersebut agar dapat memosisikan diri, kapan tindakan dapat preventif dilakukan dan kapan tindakan represif dibutuhkan.

\section{Ucapan Terima Kasih (Acknowledgement)}

Terimakasih disampaikan kepada pihak-pihak yang terlibat dalam penelitian ini. Terimakasih juga kepada pihak Universitas yang telah mendukung penelitian ini. 


\section{REFERENSI}

Arief, B. N. (2008).. Bunga Rampai Kebijakan Hukum Pidana Edisi Kedua. Jakarta: Kencana.

Badan Nasional Penanggulangan Terorisme (BNPT). (2016). Strategi Menghadapi Paham Radikalisme Terorisme - ISIS. Jakarta: Belmawa.

Kamus Besar Bahasa Indonesia. (1995). Departemen pendidikan dan kebudayaan."Radikalisme". Jakarta: Balai Pustaka.

Firmansyah, H. (2011).Upaya Penanggulangan Tindak Pidana Terorisme Di Indonesia. Mimbar Hukum, 23(2). Murya, Adnan \&Sucipto, U. (2016). Etika dan Tanggung Jawab Profesi. Yogyakarta: Deepublish.

Purwanto, W.H. (2007). Terorisme Undercover, Memberantas Terorisme hingga ke AkarAkarnya, Mungkinkah?. Jakarta: CMB Press

Shidarta. (2009). Moralitas Profesi Hukum: suatu tawaran kerangka berpikir. Bandung: Refika.

Supeno, H. (2010). Kriminalisasi anak: tawaran gagasan radikal peradilan anak tanpa pemidaan. Jakarta: Gramedia Pustaka Utama.

Tjahjono, H. (2011_. Cultur based leadership. Jakarta: Gramedia Pustaka Utama.

Republik Indonesia. (2002). Undang-Undang Republik Indonesia Nomor 2 Tahun 2002 Tentang Kepolisian Negara Republik Indonesia.

Peraturan Kepala Kepolisian Negara Republik Indonesia Nomor 8 Tahun 2009 tentang Implementasi Prinsip dan Standar Hak Asasi Manusia dalam Penyelenggaraan Tugas Kepolisian Negara Republik Indonesia. 